\title{
Changes in Microbial Activity of Sheep Milk Yoghurt during Storage at Ambient Temperature $\left(35 \pm 2^{0} \mathrm{C}\right)$
}

\author{
Amit Kumar Barman ${ }^{1 *}$, Pradip Kumar Roy ${ }^{1}$, Subhajit Ray ${ }^{2}$, Rakesh Kumar ${ }^{3}$, \\ Binita Rani ${ }^{3}$ and Bipin Kumar Singh ${ }^{3}$
}

${ }^{1}$ WBUAFS, Mohanpur campus, Nadia-741252, W.B., India

${ }^{2}$ CIT, Assam: 783370, India

${ }^{3}$ S.G.I.D.T. BASU, Patna-800014, India

*Corresponding author

\section{A B S T R A C T}

\section{Keywords \\ Goat milk yoghurt, Ambient temperature $\left(35 \pm 2^{0} \mathrm{C}\right)$, Acid development, coliform count, Standard plate count, Proteolytic activity, Diacetyl and acetoin content. \\ Article Info \\ Accepted: 28 September 2017 Available Online: 10 October 2017}

Changes in microbial activity was studied during ambient storage of sheep milk yoghurt. The starter cultures were one pure stain of Yoghurt YH-3 and another mixed culture of Steptococcus salivarious var. thermophilus-YH-S + Lactobacillus delbrueckii var. bulgaricus (1:1). The rate of inoculum in the preparation of sheep milk yoghurt was $3 \%$ in both the types of preparation. The acid production increase with the period of storage for both the types of preparation. However the rate of acidity development is faster in case of mixed culture. After $8 \mathrm{hrs}$ of storage at room temperature $\left(35 \pm 2^{0} \mathrm{C}\right)$ the acidity crosses the desirable level. In case of pure culture preparation the viable cells count increases upto 8 hrs of storage, then gradually decreases in number. But for mixed culture preparation the counts shows increasing trend upto $16 \mathrm{hrs}$, then decreases. Coliform count shows decreasing trend as the time proceeds. But the proteolytic activity increases during storage. In both the types of preparations diacetyl and acetoin production increase upto $8 \mathrm{hrs}$ and then slow declining trend. The mixed culture shows higher production of flavouring compounds.

\section{Introduction}

Nearly every civilization has consumed cultured milk of one or another and these products have been, and still are, of extreme importance throughout the world due to its higher nutritional and therapeutic properties. Ancient physicians of the Middle East prescribed yoghurt as a cure for gastrointestinal disorders.

Fermented products from goat milk played in the past a very significant role, securing food and money for rural people of many developing countries including India. Certainly these fermented milk products will also play equally important for some developing countries in future.

Government regulations, where elaborated, do not allow any health claims for yoghurt and scientific evidence on that subject has not been clearly forth coming. The considerable growth in consumption over the years has been due to its agreeable organoleptic properties, the availability of large variety of 
flavoured products and to its public image as a "healthy" food.

India has the largest sheep population in the world possessing more than 65 million and contributing $1.4 \%$ of milk annually. The economy of sheep farming can be enhanced further if milk can be suitably processed and converted into value added products including yoghurt. Yoghurt is made successfully from Sheep milk (Fikkin et al., 1986; Yaygin and Mehanna, 1988 and Kehagias et al., 1987) a blending with cow milk (Yajima et al., 1992) or admixing cow, buffalo and camel milk (Jandal, 1988). Scientific and technological development for the production of various cultured milk products including yoghurt from sheep milk has been reviewed by (Mann 1991 and 1994).

\section{Materials and Methods}

\section{Source of milk}

Fresh raw sheep milk was obtained from a private herd situated at Haringhata.

\section{Source of starter cultures}

Five types of culture were used for the preparation of yoghurt were collected from National collection of dairy cultures, NDRI, Karnal.

Yoghurt YH-3

Steptococcus salivarious var. thermophilus$\mathrm{YH}-\mathrm{S}$

Lactobacillus delbrueckii var. bulgaricus

Lactobacillus acidophilus

Bifidobacterium bifidum

Pathogenic test organisms Escherichia coli and Salmonella typhimurium were obtained from the department of Veterinary Microbiology, West Bengal University of Animal and Fishery Sciences.

\section{Chemicals}

The chemicals used in the experiments were of analytical grade and chemically pure quality.

\section{Microbiological analysis}

For the estimation of various microbial population in the sample of yoghurt the microbiological examinations along with titratable acidity were carried out at ambient storage temperature $\left(35 \pm 2^{0} \mathrm{C}\right)$ till the quality remained good in terms of the following tests:

Titratable acidity (BIS : 1960 ; IS : 1479)

Standard plate count (IS : 1479 ; BIS : 1962)

Coliform count (BIS: 1981 ; SP: 18)

Proteolytic activity (Hull, 1947)

Diacetyl and Acetoin content (King, 1948)

\section{Revival of cultures}

The cultures were revived in accordance with the instructions supplied by N. D. R. I., Karnal. They were as follows:

The outer surfaces of the cultures ampoules were wiped with cotton previously soaked in $75 \%$ alcohol.

Made a mark with a file about $0.25 \mathrm{~cm}$ long near the top of the ampoule.

The ampoule was broken near the flame with a twist in opposite direction of the mark holding the ampoule by both the hands.

This was done with care to avoid rapid rush of air into the tube.

Added $0.2 \mathrm{ml}$ (6-8 drops) of tyndallised skim milk (10\%) using sterile fine tip pipette.

Scrapped the contents to dissolve fully and transferred the suspension into 1-2 tyndallised skim milk tube (10 $\mathrm{ml}$ each). 
Shake the tube and incubated at recommended growth temperature $\left(37^{0} \mathrm{C}\right)$ until coagulated/enough growth as evidence by turbidity.

Subcultured thrice in litmus milk to obtain fully active growth of cultures.

\section{Preparation of litmus milk}

\section{Composition}

Prepare 5\% solution of litmus milk (blue). Litmus solution saturated $-2 \mathrm{ml}$ Fresh skim milk - $100 \mathrm{ml}$
It was distributed in test tubes with $10 \mathrm{ml}$ in each test tube and auto-claved at 15 psi for 15 minutes. Litmus milk for culture propagation was tyndallised.

\section{Results and Discussion}

From the observation it can be stated that the acidity increases with the increase in the time period significantly. The rate of acidity development is faster by second starter (Table-2) at each step of observation. After 8 hrs of storage at room temperature $\left(35 \pm 2^{0} \mathrm{C}\right)$, the acidity level cross the desirable level.

Table.1 Profile of the titratable acidity, standard plate count, coliform count, proteolytic activity and diacetyl \& acetoin content during fermentation $\left(42 \pm 1^{0} \mathrm{C}\right)$ and storage at ambient temperature $\left(35 \pm 2^{0} \mathrm{C}\right)$ of sheep milk yoghurt

\begin{tabular}{|c|c|c|c|c|c|c|c|}
\hline \multirow{2}{*}{$\begin{array}{c}\text { Type of culture } \\
\text { used }\end{array}$} & \multirow{2}{*}{ Parameters } & \multicolumn{2}{|c|}{ Incubation (h) } & \multirow{2}{*}{$\begin{array}{l}\text { Product } \\
(\text { (0h) }\end{array}$} & \multicolumn{3}{|c|}{ Storage } \\
\hline & & Oh & $4 \mathrm{~h}$ & & $8 \mathrm{hh}$ & $16 \mathrm{~h}$ & $24 \mathrm{~h}$ \\
\hline \multirow{5}{*}{$\begin{array}{c}\text { Yoghurt-YH-3 } \\
@ 3 \%\end{array}$} & Titratable acidity (\% LA) & 0.126 & 0.755 & 0.855 & 0.990 & 1.143 & 1.278 \\
\hline & $\begin{array}{l}\text { Standard Plate Count } \\
(\log \text { c.f.u./ml })\end{array}$ & 4.17 & 6.94 & 7.13 & 7.32 & 7.05 & 6.97 \\
\hline & Coliform count (log c.f.u./ml) & 0 & 10 & 5 & 5 & 5 & 0 \\
\hline & $\begin{array}{c}\text { Proteolytic activity (mg } \\
\text { tyrosine/g) }\end{array}$ & - & 0.125 & 0.1375 & 0.150 & 0.2125 & 0.225 \\
\hline & $\begin{array}{c}\text { Diacetyl \& Acetoin content } \\
(\mathrm{ppm})\end{array}$ & - & 2 & 4 & 9 & 7 & 6 \\
\hline
\end{tabular}

* Values are the average of three replications.

Table.2 Profile of the titratable acidity, standard plate count, coliform count, proteolytic activity and diacetyl and acetoin content during fermentation $\left(42 \pm 1^{\circ} \mathrm{C}\right)$ and storage at ambient temperature $\left(35 \pm 2^{0} \mathrm{C}\right)$ of sheep milk yoghurt

\begin{tabular}{|c|c|c|c|c|c|c|c|}
\hline \multirow{2}{*}{$\begin{array}{c}\text { Type of culture } \\
\text { used }\end{array}$} & \multirow[t]{2}{*}{ Parameters } & \multicolumn{2}{|c|}{ Incubation (h) } & \multirow[b]{2}{*}{$\begin{array}{l}\text { Product } \\
\text { (0h) }\end{array}$} & \multicolumn{3}{|c|}{ Storage } \\
\hline & & $\mathbf{O h}$ & $4 \mathrm{~h}$ & & $8 \mathrm{sh}$ & $16 \mathrm{~h}$ & $24 h$ \\
\hline \multirow{5}{*}{$\begin{array}{c}\text { Steptococcus } \\
\text { salivarious var. } \\
\text { thermophilus-YH- } \\
\mathrm{S}+\text { Lactobacillus } \\
\text { delbrueckii var. } \\
\text { bulgaricus }(1: 1) \\
\text { @ 3\% }\end{array}$} & Titratable acidity (\% LA) & 0.126 & 0.702 & 0.810 & 0.990 & 1.17 & 1.314 \\
\hline & $\begin{array}{l}\text { Standard Plate Count } \\
(\log \text { c.f.u./ml })\end{array}$ & 4.14 & 6.29 & 7.09 & 7.80 & 8.10 & 7.90 \\
\hline & Coliform count ( $\log$ c.f.u. $/ \mathrm{ml})$ & 0 & 10 & 9 & 10 & 6 & 0 \\
\hline & $\begin{array}{c}\text { Proteolytic activity (mg } \\
\text { tyrosine/g) }\end{array}$ & - & 0.0625 & 0.075 & 0.100 & 0.1125 & 0.175 \\
\hline & $\begin{array}{l}\text { Diacetyl \& Acetoin content } \\
(\mathrm{ppm})\end{array}$ & - & 6 & 10 & 12 & 12 & 12 \\
\hline
\end{tabular}

* Values are the average of three replications. 
From the table- 1 it is evident that the viable cells count increase upto 8 hrs of storage then gradually decrease in number. So higher the acidity of the product lower the viable cell number. But from the table- 2 it is observed that upto $16 \mathrm{hrs}$ of storage the viable cells count increase in number, and then decline. Coliform counts decrease in number as the time goes.

But the proteolytic activity increases during storage. It is due to higher activity of starter organisms. Though it is found that the proteolytic activity increases inspite of decrease of viable cells count, it is due to activity of proteolytic enzymes secreted by organisms in milk.

Comparatively proteolytic activity is higher in each step of observation. Diacetyl and action content increase upto $8 \mathrm{hrs}$ of storage, and then decline in amount (Table-1).

Similar observations are also seen from table2 , but the content remains same upto $24 \mathrm{hrs}$. Comparatively, Yoghurt YH-3 culture produces less amount of flavouring compounds than an equivalent mixing of $S$. salivarious var. thermophilus $\mathrm{YH}-\mathrm{S}$ and $L$. delbrueckii var. bulgaricus.

In both the cases the amount of diacetyl and acetoin produced by starters are higher than that shown by (Yaygin, 1982) 0.2-0.3 ppm.

\section{References}

Fikkin, A., Palov, D. and Boichinov, E. 1986. Khranitelnoprmishiens Nouka. 2: 40.

Jandal, J. M., and Rai, T. 1988. Free fatty acids in milks and milk products - a review. Agric. Rev. 9 (4): 217.

Kehagias, H. H.; Konidare, P. G.; Laskaris, H. I. and Karazes, I. S. (1987). Fermentation of cows, goats and ewes milk by thermophilic acid producing cultures. Episteme Kai Technologia Galaktos. 4 (1): 43.

Mann, E. J., 1991. Ewes, goats' milk. Part-I. Dairy Indus. Int. 56 (10-11): 17.

Mann, E. J., 1994. Yoghurt and related products. Part-II. Dairy Indus. Int. 59 (4): 18.

Yajima, M., Hashimoto, S.; Saita, T. and Matsuzaki, K. 1992. Method of preparing milk - fermented food. European Patent Application EPO 486738-AL, $12 \mathrm{p}$.

Yaygin, H., 1982. Contents of acetaldehyde and other volatile aromatic compounds in yoghurt from ewes, goats and buffaloes milk. XXI Int. Dairy Congr. Vol-1, Book-2, Moscow, USSR, Mir Pub., 294 p.

Yaygin, H., and Mehanna, N. M. 1988. A comparative study on some volatile flavour components of yoghurt made from milk of different species. Indian $J$. Dairy Sci. 41: 432.

\section{How to cite this article:}

Amit Kumar Barman, Pradip Kumar Roy, Subhajit Ray, Rakesh Kumar, Binita Rani and Bipin Kumar Singh. 2017. Changes in Microbial Activity of Sheep Milk Yoghurt during Storage at Ambient Temperature (35 $\pm 2^{0}$ C). Int.J.Curr.Microbiol.App.Sci. 6(10): 3430-3433. doi: https://doi.org/10.20546/ijcmas.2017.610.404 